\title{
Influence of Norepinephrine and Exercise on Lipolysis in Adipose Tissue of Diabetic Rats
}

\author{
V.A. Koivisto, E. A. Nikkilä and H. K. Åkerblom \\ The Children's Hospital and Third Dept. of Medicine, University of Helsinki, Helsinki and Dept. of Pediatrics, University of Oulu, Oulu, \\ Finland
}

Received: January 20, 1975, and in revised form: May 26, 1975

\begin{abstract}
Summary. The lipolytic effect of norepinephrine (NE) in adipose tissue in vitro was studied before and after exercise in non-fasted rats with severe, untreated streptozotocin diabetes. It was observed that: 1 . NE in increasing concentrations stimulated glycerol release in vitro to an equal extent from the adipose tissue of nondiabetic and diabetic rats. However, the re-esterification of free fatty acids (FFA) in adipose tissue in vitro was decreased by NE in diabetic rats as compared to normal rats. 2. During exercise NE further decreased the re-esterification of FFA in vitro in adipose tissue of diabetic rats. 3. Exercise did not change NE-induced glycerol release in vitro in the adipose tissue of diabetic rats. 4 . In
\end{abstract}

diabetic animals the increase in plasma glycerol and FFA during exercise was correlated inversely with the NE-induced release of glycerol and FFA from the adipose tissue of the same animals after exercise. The lipolytic effect of NE is not significantly different in adipose tissue of diabetic and nondiabetic rats. By decreasing the re-esterification of FFA in vitro, NE is probably responsible for the observed increase in the release of FFA in vivo, a likely energy source in severely diabetic animals.

Key words: Adipose tissue, catecholamines, diabetes, exercise, free fatty acids, glycerol, lipolysis, rat, streptozotocin.
In untreated diabetic patients exercise induces a higher rise in plasma catecholamines $[6,7]$ and a more intense lipid mobilization $[5,13]$ than in nondiabetic subjects.The increased lipolysis in diabetic adipose tissue is at least partly due to the high level of circulating catecholamines [6]. Adequate insulin treatment decreases plasma catecholamines $[6,7]$ and lipolysis [5] during exercise.

It is hitherto unresolved whether the enhanced lipolysis in diabetes induced by exercise is due to lack of insulin and the associated rise in lipolytic hormones or whether exercise alters the sensitivity of diabetic adipose tissue to lipolytic hormones, e.g. to catecholamines. We have accordingly studied, in diabetic animals, the norepinephrine (NE)-induced release of glycerol and free fatty acids (FFA) in vitro before and after exercise and lipid mobilization in vivo during exercise.

\section{Materials and Methods}

\section{Rats}

Male Sprague-Dawley rats, weighing 300 to $350 \mathrm{~g}$ were used. Streptozotocin (Upjohn \& Co., lot 968L-GGS-118FJ) was freshly prepared in 0,1 molar citrate buffer, $\mathrm{pH} 4,5$, and injected intravenously into fed animals in a dose of $65 \mathrm{mg} / \mathrm{kg}$ body weight. The rats were fed a normal commercial chow ${ }^{1}$ ad libitum until the experiment, which started $42-48 \mathrm{~h}$ after the administration of streptozotocin. During this time the weight loss of untreated diabetic animals was $30 \pm 3 \mathrm{~g}$ (mean $\pm \mathrm{SEM} ; \mathrm{n}=32$ ), whereas control animals gained weight $9 \pm 2 \mathrm{~g}(\mathrm{n}=31)$.

\section{Experimental Design}

Norepinephrine dose response of adipose tissue lipolysis in vitro was studied in 12 control and 12 diabetic rats. Animals were killed and epididymal fat pads were immediately removed and placed into incubation medium, which was Krebs-Ringer bicarbonate buffer containing $3 \mathrm{~g} / 100 \mathrm{ml}$ of bovine serum albumin (Armour, Fraction V) and increasing concentrations of norepinephrine $(0,0.05,0.1,1.0$ or $10.0 \mu \mathrm{g} / \mathrm{ml}$ ). Each pad was then divided into eight parts of approximately equal size and these were weighed. The pieces were placed into flasks which were equilibrated with $95 \% \mathrm{O}_{2}-5 \% \mathrm{CO}_{2}$ during the five minutes of preincubation and during the first five minutes of incubation.

The effect of exercise on lipolysis in vivo and in vitro was studied in 21 control and 20 diabetic rats, which were each divided into two groups. Animals of one

1 The chow contains by weight carbohydrate $53.0 \%$, protein $20.9 \%$, fat $4.5 \%$, fiber $3.9 \%$ and usual vitamins and minerals. 
group were killed while at rest, whereas the rats of the other group were forced to run for $30 \mathrm{~min}$ in a rotating cage and killed immediately afterwards. Epididymal fat pads were rapidly removed, divided into four parts, weighed and incubated in the presence or absence of norepinephrine $(1.0 \mu \mathrm{g} / \mathrm{ml})$ as described above.

An aliquot of the medium for the determination of glycerol [10] and FFA [14] was taken after the preincubation period (zero time reading) and at the end of the incubation. After the preincubation period the media of diabetic and control adipose tissue contained glucose $0.3 \pm 0.1 \mathrm{mg} / 100 \mathrm{ml}$ (mean $\pm \mathrm{SEM}$ ) and 0.2 $\pm 0.1 \mathrm{mg} / 100 \mathrm{ml}$, respectively. Glucose was apparently liberated from the blood remaining in the adipose tissue. Before the rats were killed and epididymal fat removed, specimens for the determination of blood glucose [8], plasma glycerol and plasma FFA were drawn from the retro-orbital venous plexus of rats lightly anaesthetized with ether. The medium and the plasma specimens were kept at $-20^{\circ} \mathrm{C}$ until analyzed.

The re-esterification of FFA was calculated by using the following formula, which is based on the assumption that glycerol was not reutilized for esterification:

$$
\frac{[\text { glycerol release } \times 3]-[\text { FFA release }]}{[\text { glycerol release } \times 3]} \times 100
$$

where,

(glycerol release $\times 3$ ) $=\mu \mathrm{mol}$ of FFA originating from complete lipolysis,

(FFA release) $=\mu \mathrm{mol}$ of $\mathrm{FFA}$ released into the medium,

$($ glycerol release $\times 3)-($ FFA release $)=$ the amount of FFA re-esterified [11].

\section{Results}

\section{Norepinephrine Dose Response}

The diabetic animals had significantly higher blood glucose $(342 \pm 22$ vs $89 \pm 4 \mathrm{mg} / 100 \mathrm{ml}$, mean \pm SEM), plasma glycerol $(0.20 \pm 0.04$ vs $0.09 \pm 0.01$ $\mathrm{mM})$ and FFA $(1.13 \pm 0.12$ vs $0.41 \pm 0.04 \mathrm{mM})$ levels than the control rats.

Release of Glycerol. The basal release of glycerol was higher from the adipose tissue of diabetic rats $(p<$ 0.001 ), but the norepinephrine dose response curves were parallel in both groups (Fig. 1).

Release of FFA. The basal net release of FFA from the adipose tissue of diabetic rats was elevated as compared to normal, $p<0.001$ (Fig. 1). The difference was further increased by norepinephrine at con-
Table 1. The index of FFA re-esterification in adipose tissue of nondiabetic and diabetic rats. The fat pads were incubated in vitro in the presence of norepinephrine

\begin{tabular}{lll}
\hline & \multicolumn{2}{l}{ Re-esterification index \% } \\
\cline { 2 - 3 } $\begin{array}{l}\text { Norepinephrine } \\
\text { concentration, } \mu \mathrm{g} / \mathrm{ml}\end{array}$ & 0.05 & 0.1 \\
\hline Nondiabetic & $59.2 \pm 4.6^{\mathrm{a}}$ & $45.4 \pm 9.3^{\mathrm{b}}$ \\
$\mathrm{n}$ & 6 & 12 \\
$\begin{array}{l}\text { Diabetic } \\
\mathrm{n}\end{array}$ & $32.2 \pm 7.9^{\mathrm{a}}$ & $24.1 \pm 4.4^{\mathrm{b}}$ \\
\hline
\end{tabular}

$$
\mathrm{a}=p<0.02
$$

$\mathrm{b}=p<0.05$

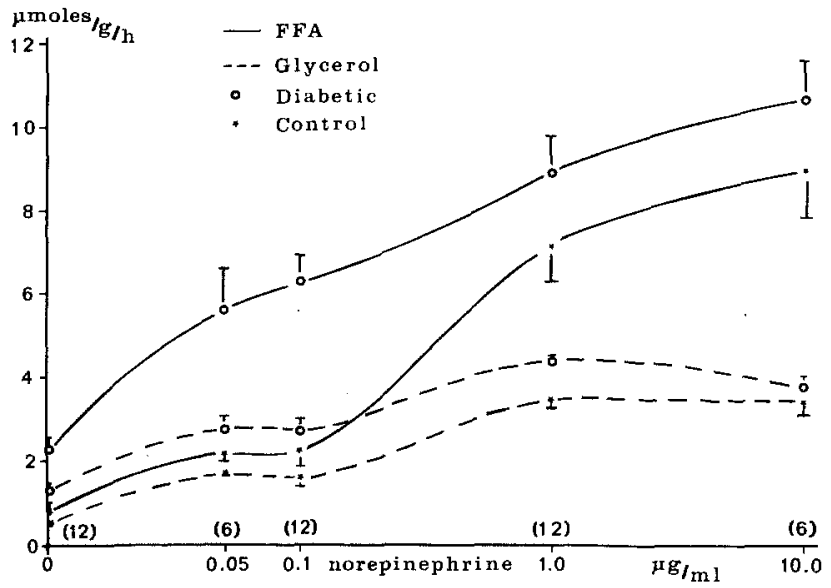

Fig. 1. The effect of norepinephrine on the release of glycerol and net release of FFA in vitro in adipose tissue of control and streptozotocin-diabetic rats. The number of animals was the same in both groups and is given in brackets

centrations 0.05 and $0.1 \mu \mathrm{g} / \mathrm{ml}$ (Fig. 1). At these two concentrations the FFA re-esterification was impaired in diabetic adipose tissue as compared to normal (Table 1).

\section{Exercise}

The blood glucose, glycerol and FFA levels of rats subjected to exercise are given in Table 2. During exercise blood glucose increased in nondiabetic animals, but did not change in diabetic rats. Plasma glycerol increased in both groups, but circulating FFA rose only in control animals. In control and diabetic rats killed without exercise blood glucose, $(92 \pm 5$ and $378 \pm 38 \mathrm{mg} / 100 \mathrm{ml})$, glycerol $(0.07 \pm 0.01$ and 0.11 $\pm 0.01 \mathrm{mM})$ and FFA $(0.26 \pm 0.03$ and $0.55 \pm 0.03$ $\mathrm{mM}$ ) were, except for FFA in controls, similar to the pre-exercise values of rats subjected to exercise.

Release of Glycerol. Exercise did not influence the 
Table 2. The levels of circulating glucose, glycerol and FFA before and after exercise in nondiabetic and streptozotocin $(65 \mathrm{mg} / \mathrm{kg})$-diabetic rats. Mean $\pm S E M$ and the number of animals are given

\begin{tabular}{|c|c|c|c|c|}
\hline & \multicolumn{2}{|l|}{ Nondiabetic } & \multicolumn{2}{|l|}{ Diabetic } \\
\hline & $\begin{array}{l}\text { Before } \\
\text { exercise }\end{array}$ & After & $\begin{array}{l}\text { Before } \\
\text { exercise }\end{array}$ & After \\
\hline Blood glucose, $\mathrm{mg} / 100 \mathrm{ml}$ & $106 \pm 2^{\mathrm{a}}[9]$ & $138 \pm 7^{\mathrm{a}}[10]$ & $365 \pm 18^{\mathrm{b}}[10]$ & $337 \pm 19^{\mathrm{b}}[10]$ \\
\hline Plasma glycerol, $\mathrm{mM}$ & $0.06 \pm 0.01^{\mathrm{a}}[9]$ & $0.16 \pm 0.01^{\mathrm{a}}[10]$ & $0.11 \pm 0.02^{\mathrm{a}}[10]$ & $0.27 \pm 0.03^{\mathrm{a}}[10]$ \\
\hline Plasma FFA, mM & $0.17 \pm 0.01^{c}[9]$ & $0.26 \pm 0.03^{c}[10]$ & $0.63 \pm 0.08^{b}[10]$ & $0.56 \pm 0.08^{b}[10]$ \\
\hline
\end{tabular}

Significance of difference between pre- and postexercise values, $\mathrm{a}=p<0.001, \mathrm{~b}=$ not significant, $\mathrm{c}=p<0.02$

a)GLYCEROL RELEASE AT REST

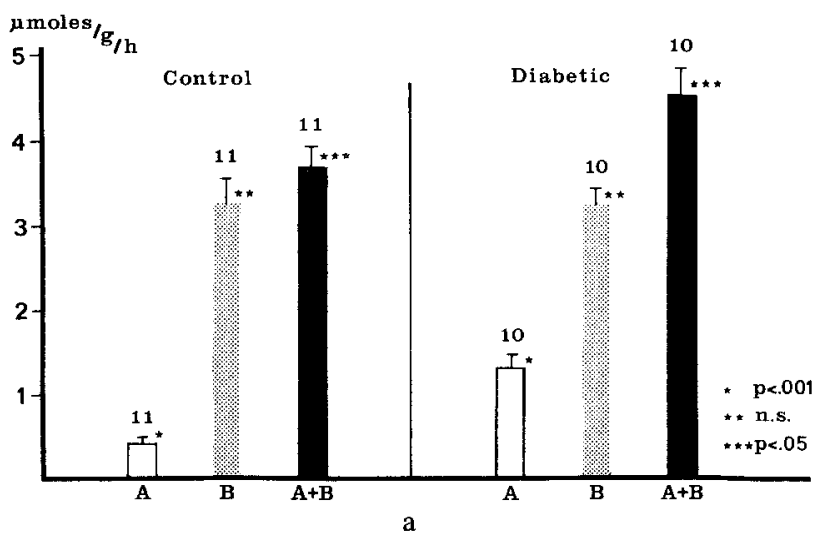

b) GLYCEROL RELEASE AFTER EXERCISE

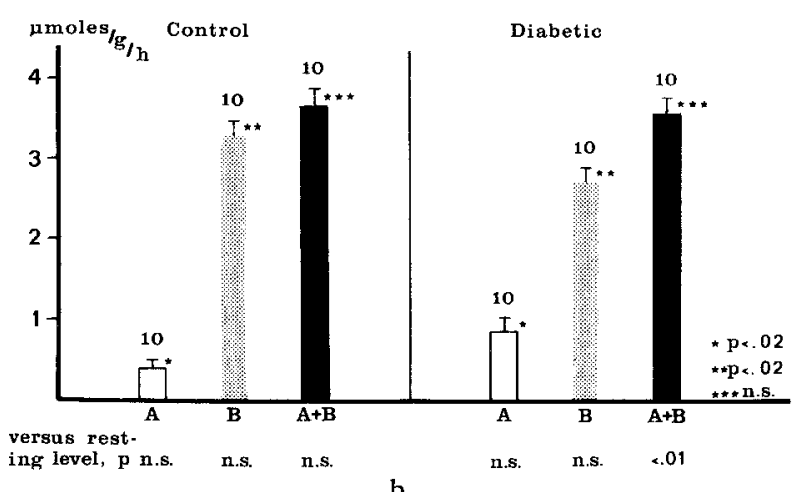

Fig. 2. The in vitro release of glycerol from adipose tissue of control and streptozotocin-diabetic rats a) at rest and b) after $30 \mathrm{~min}$ exercise. The number of animals is shown above each column. $\mathrm{A}=$ basal release of glycerol, $\mathrm{B}=$ norepinephrine $(1.0 \mu \mathrm{g} / \mathrm{ml})-\mathrm{stimulated} \mathrm{release} \mathrm{of}$ glycerol. n.s. = not significant. Asterisks show the difference between control and diabetic rats

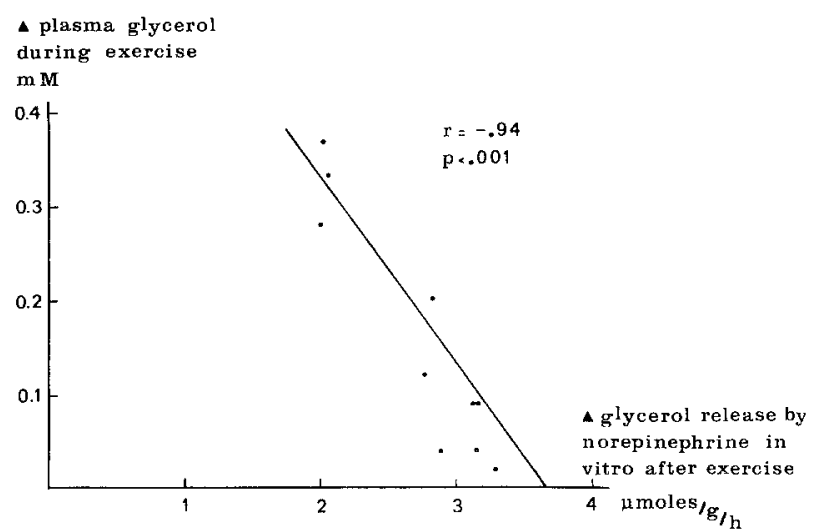

Fig. 3. Correlation between the rise in plasma glycerol during exercise and the norepinephrine-induced glycerol release after exercise in vitro in adipose tissue of streptozotocin-diabetic rats

basal or NE-stimulated release of glycerol from adipose tissue of nondiabetic rats, but in diabetic animals the total lipolytic activity (basal + stimulated) was significantly decreased by exercise (Figs. 2a and b).
In diabetic animals there was a highly significant negative correlation between the NE-induced rise in glycerol release in vitro after exercise and the rise in plasma glycerol in the same animals during exercise (Fig. 3), $(\mathrm{r}=-0.94, p<0.001)$. In the control group no such correlation was found $(\mathrm{r}=+0.08)$.

Release of FFA. Exercise did not diminish the total net release of FFA in vitro from adipose tissue of diabetic animals (Figs. 4a and b), although the release of glycerol had decreased during exercise. The reesterification index of FFA decreased significantly during exercise in diabetic, but not in normal, adipose tissue incubated with NE (Fig. 5). The re-esterification of FFA remained unchanged during exercise in both groups, when adipose tissue was incubated without NE.

In diabetic animals the NE-induced release of FFA in vitro after exercise correlated inversely with the change in plasma FFA during exercise $(\mathrm{r}=-0.85, p$ $<0.001$ ) (Fig. 6). In control rats no such correlation was found $(\mathrm{r}=+0.12)$. 
b) NET FFA RELEASE AFTER EXERCise

a) NET FFA RELEASE AT REST

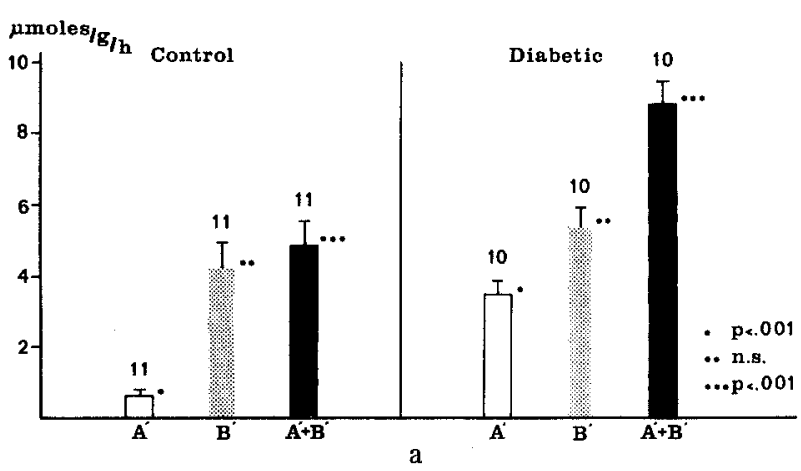

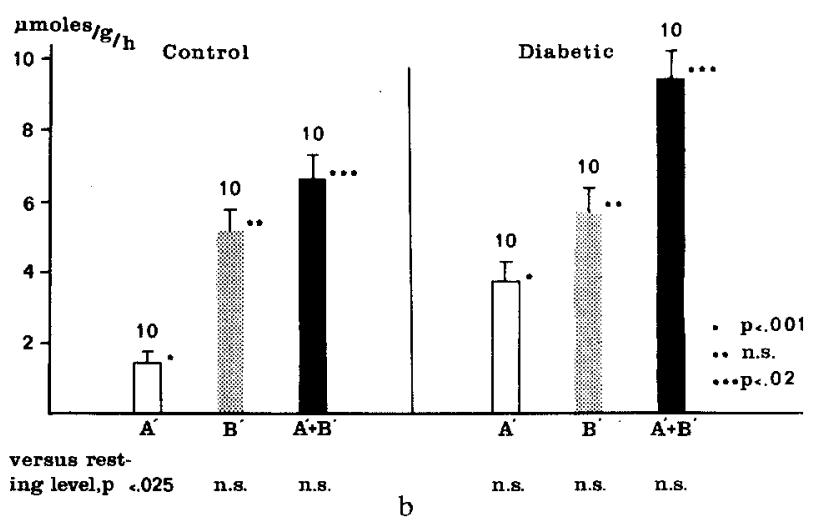

$\mathrm{b}$

Fig. 4. The net release of FFA in vitro in adipose tissue of control and streptozotocin-diabetic rats a) at rest and b) after $30 \mathrm{~min}$ exercise. The number of animals is shown above each column. Symbols A and B and the asterisks are explained in Fig. 2

a) AT REST

b) AFTER EXERCISE

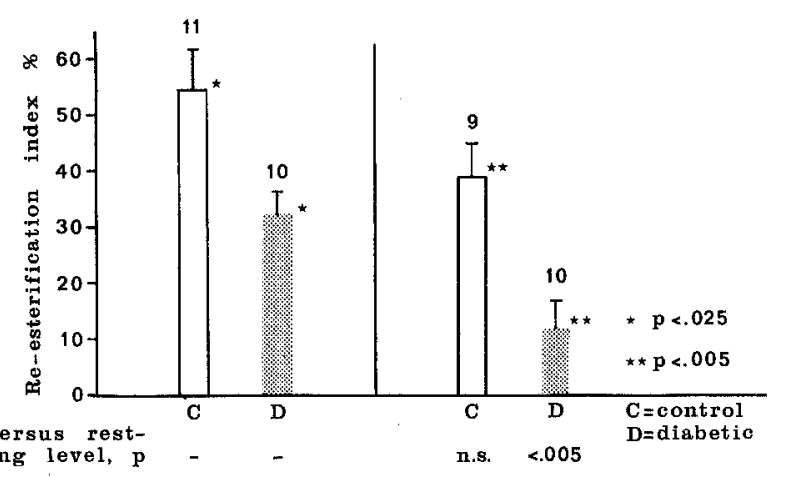

Fig. 5. The re-esterification of FFA in vitro in adipose tissue of control and streptozotocin-diabetic rats a) at rest and b) after 30 min exercise. The incubation medium contained norepinephrine $1.0 \mu \mathrm{g} / \mathrm{ml}$. The number of animals is shown above each column. Asterisks show the difference between control and diabetic rats

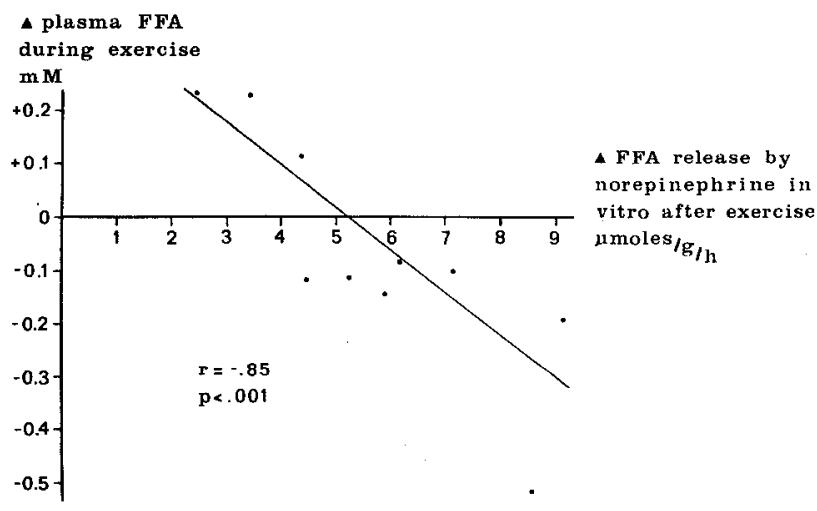

Fig. 6. Correlation between the change in plasma FFA during exercise and the norepinephrine-induced net release of FFA after exercise in vitro in adipose tissue of streptozotocin-diabetic rats

\section{Discussion}

In the present experiments NE induced a similar glycerol release from adipose tissue of both diabetic and nondiabetic rats. The result is in agreement with that of Berger, who found that the lipolytic response to NE is similar in adipose tissue of human diabetic and nondiabetic subjects [1].

According to the data of glucose uptake into adipose tissue presented by Cahill et al. [4] and Östman [15] the glucose concentration of $0.2-0.3$ $\mathrm{mg} / 100 \mathrm{ml}$ in our media should be high enough, tcgether with the small stores of glycogen in the tissue [12], for the formation of $\alpha$-glycerophosphate, and the re-esterification of FFA can occur in vitro.

The higher net release of FFA in vitro from the adipose tissue of diabetic rats was evidently not caused by increased lipolysis, but was accounted for by an impaired re-esterification of FFA induced by NE. Zapf et al. have recently reported that NE induced greater lipolysis and mobilization of FFA in the adipose tissue of diabetic than control rats [19]. This discrepancy between their and our results could be partly explained by our finding of decreased FFA re-esterification due to NE.

In our study exercise did not alter the sensitivity of diabetic adipose tissue to NE in vitro. This finding suggests that the high lipolytic rate of diabetic adipose tissue is not due to basal or exercise-induced greater sensitivity of the tissue to NE. Accentuated lipolysis might be related to an excessive response of several lipolytic hormones to exercise during insulin deficiency.

Diabetic animals showed a high-grade inverse correlation a) between the rise in plasma glycerol during exercise and NE-induced glycerol release in 
vitro after exercise, and also $\mathrm{b}$ ) between the change in plasma FFA during exercise and the NE-induced net release of FFA in vitro after exercise. These observations could be explained by assuming that when more beta receptors, which mediate the lipolytic effect of catecholamines on fat cells [3], were occupied by high levels of circulating catecholamines during exercise $[2$, $6,7]$, the binding of NE added in vitro was decreased.

In nondiabetic rats Lefebvre et al. showed a slight decrease in FFA re-esterification after $30 \mathrm{~min}$ exercise [11]. Our results in normal rats confirm this finding. In diabetic rats, however, the re-esterification of FFA in vitro was clearly decreased by NE during exercise. The finding of impaired FFA re-esterification by NE offers a new aspect in energy production in diabetes. Besides the fact that NE inhibits insulin secretion [16], stimulates lipolysis and hepatic glycogenolysis [18] and increases glucagon secretion [17], all effects which promote energy mobilization, $\mathrm{NE}$ also decreases FFA re-esterification at rest and further during exercise in insulin deficient animals, which use predominantly FFA as energy for muscular work [9].

Acknowledgements. The technical assistance of Mrs. Satu Akerberg and Miss Leena Savolainen, the financial support from the Finnish State Medical Research Council (Academy of Finland) (V.A.K., E.A.N.) and the facilities given by the Foundation for Pediatric Research, are acknowledged.

\section{References}

1. Berger, M.: Untersuchung zur Lipolyse am menschlichen Fettgewebe in vitro. Thesis. Düsseldorf 1969

2. Bernet, F., Denimal, J.: Evolution de la réponse adrénosympathique á l'exercise au cours de l'entrainement chez le rat. Europ. J. appl. Physiol. 33, 57-70 (1974)

3. Burns, T. W., Langley, P.E.: Lipolysis by human adipose tissue: The role of 3', 5'-adenosine monophosphate and adrenergic receptor sites. J. Lab. clin. Med. 75, $983-997$ (1970)

4. Cahill, G.F., Jr., Leboeuf, B., Flinn, R.B.: Studies on rat adipose tissue in vitro. J. biol. Chem. 235, 1246-1250 (1960)

5. Carlström, S.: Studies on fatty acid metabolism in diabetics during exercise. VII. Plasma glycerol concentrations in juvenile diabetics during exercise before and after adequate insulin treatment. Acta med. scand. 186, 429-432 (1969)

6. Christensen, N.J.: Plasma epinephrine and norepinephrine concentrations in early diabetes. Adv. Metab. Dis., Suppl. 2, 227-233 (1970)

7. Christensen, N.J.: Plasma norepinephrine and epinephrine in untreated diabetics, during fasting and after insulin administration. Diabetes 23, 1-8 (1974)

8. Huggett, A.St.G., Nixon, D.A.: Enzymatic determination of blood glucose. Biochem. J. 66, 12 (1957)

9. Koivisto, V.A., Åkerblom, H.K., Kiviluoto, M.K.: Metabolic and hormonal effects of exercise in severely steptozotocindiabetic rats. Diabetologia 10, 329-335 (1974)

10. Laurell, S., Tibbling, G.: An enzymatic fluorimetric micromethod for the determination of glycerol. Clin. chim. Acta 13, 317-322 (1966)

11. Lefebvre, P.J., Luyckx, A.S., Federspil, G.: Muscular exercise and pancreatic function in rats. Irish J. med. Sci. 8, 390-398 (1972)

12. Mukherjee, S.P., Mukherjee, C.: Control of rat adipose tissue metabolism by cortisone in relation to epinephrine. Amer. J. Physiol. 224, 898-903 (1973)

13. Nordlander, S., Östman, J., Cerasi, E., Luft, R., Ekelund, L.-G.: Occurrence of diabetic type of plasma FFA and glycerol responses to physical exercise in prediabetic subjects. Acta med. scand. 193, 9-21 (1973)

14. Novak, M.: Colorimetric ultramicro method for the determination of free fatty acids. J. Lipid Res. 6, 431-433 (1965)

15. Östman, J.: Studies in vitro on fatty acid metabolism of human subcutaneous adipose tissue in diabetes mellitus. Acta med. scand. 177, 639-655 (1965)

16. Porte, D., Jr., Williams, R.H.: Inhibition of insulin release by norepinephrine in man. Science 152, 1248-1250 (1966)

17. Porte, D., Jr., Robertson, R.P.: Control of insulin secretion by catecholamines, stress and the sympathetic nervous system. Fed. Proc. 32, 1792-1796 (1973)

18. White, A., Handler, P., Smith, E. L.: Principles of Biochemistry. 5th ed., p. 1078. New York: McGraw-Hill Book Company 1973

19. Zapf, J., Feuerlein, D., Froesch, E. R.: Enhanced sensitivity of diabetic rat adipose tissue to epinephrine: A new explanation for increased plasma FFA-levels in the diabetic state. Diabetologia 10, 391 (1974)
V.A. Koivisto, M.D.
The Children's Hospital
University of Helsinki
11 , Stenbäck Street
SF-00290 Helsinki 29
Finland 